\title{
The Dilemmas of Risk-Sensitive Development on a Small Volcanic Island
}

\author{
Emily Wilkinson ${ }^{1, *}$, Emma Lovell ${ }^{1}$, Barbara Carby ${ }^{2}$, Jenni Barclay ${ }^{3}$ and \\ Richard E.A. Robertson ${ }^{4}$ \\ 1 Climate and Environment Programme, Overseas Development Institute, London SE1 8NJ, UK; \\ e.lovell@odi.org.uk \\ 2 UWI Disaster Risk Reduction, University of the West Indies, 13 Gibraltar Camp Way, Mona, Kingston 7, \\ Jamaica; barbara.carby@uwimona.edu.jm \\ 3 School of Environmental Sciences, University of East Anglia; Norfolk NR4 7TJ, UK; J.Barclay@uea.ac.uk \\ 4 UWI Seismic Research Centre, University of the West Indies, St Augustine, Trinidad and Tobago; \\ richie_robertson@uwiseismic.com \\ * Correspondence: e.wilkinson@odi.org.uk; Tel.: +44-20-7922-0435
}

Academic Editors: Tim Prior and Anna Scolobig

Received: 4 March 2016; Accepted: 30 May 2016; Published: 9 June 2016

\begin{abstract}
In the Small Islands Developing State (SIDS) of St Vincent and the Grenadines in the Caribbean, the most destructive disasters in terms of human casualties have been the multiple eruptions of La Soufrière volcano situated in the north of St Vincent. Despite this major threat, people continue to live close to the volcano and national development plans do not include risk reduction measures for volcanic hazards. This paper examines the development options in volcanic SIDS and presents a number of conundrums for disaster risk management on the island of St Vincent. Improvements in monitoring of volcanic hazards and ongoing programmes to enhance communications systems and encourage community preparedness planning have increased awareness of the risks associated with volcanic hazards, yet this has not translated into more risk-informed development planning decisions. The current physical development plan in fact promotes investment in infrastructure in settlements located within the zone designated very high-hazard. However, this is not an anomaly or an irrational decision: severe space constraints in SIDS, as well as other historical social and economic factors, limit growth and options for low-risk development. Greater attention needs to be placed on developing measures to reduce risk, particularly from low-intensity hazards like ash, limiting where possible exposure to volcanic hazards and building the resilience of communities living in high-risk areas. This requires planning for both short- and longer-term impacts from renewed activity. Volcanic SIDS face multiple hazards because of their geography and topography, so development plans should identify these interconnected risks and options for their reduction, alongside measures aimed at improving personal preparedness plans so communities can learn to live with risk.
\end{abstract}

Keywords: disaster risk management; volcanoes; physical planning; small island developing states

\section{Introduction}

Small Island Developing States (SIDS) include two-thirds of the countries that face the highest losses as a consequence of "natural" disasters, and the costs are growing. Tropical cyclones alone cause an estimated $\$ 835$ million of damage in the Caribbean and \$178 million in the Pacific each year. These recurrent losses undermine growth and add to national debt [1].

Two decades ago, the Barbados Programme of Action (BPOA) for the Sustainable Development of SIDS noted that "Small Island Developing States face special challenges in their socio-economic development". (Established by UN General Assembly resolution 47/189, the UN Global Conference 
on the Sustainable Development of SIDS was held in Barbados from 25 April to 6 May 1994). These challenges include "smallness, remoteness, geographical dispersion, vulnerability to natural hazards, the fragility of their ecosystems, constraints on transport and communication, isolation from markets, exogenous economic and financial shocks, limited internal market, lack of natural resources, limited freshwater supplies, heavy dependence on imports and limited commodities among others" [2].

Nevertheless, the exposure of people and assets to hazards has continued to rise on SIDS, and efforts to reduce disaster risk have not kept pace with this [3]. The UN Office for Disaster Risk Reduction (UNISDR) Global Assessment Report on Disaster Risk Reduction [4] recognises that SIDS face a particularly high threat from hazards. Compared with Europe and Central Asia, for example, SIDS are expected to lose 20 times more of their capital stock each year as a result of disasters. The report concludes that, for many of these nations, future disaster losses represent an existential threat.

This paper uses St Vincent and the Grenadines (SVG) as an exemplar to assess the development problems facing volcanic SIDS in managing disaster risk (this analysis focuses on St Vincent, the largest island of SVG, where La Soufrière volcano is located). Volcanic SIDS (SIDS with one or more volcanoes capable of new eruptive activity, Table 1) comprise $46 \%$ of all SIDS and merit attention with a particular focus on volcanic risk because of the particular physical development challenges they pose. There have been five eruptions in the historical records (1700 to the present) of SVG. When La Soufrière erupts, up to one-third of the island is potentially exposed to pyroclastic flows, mudflows and ballistic projectiles, and the entire country is affected by the low-intensity but damaging effects of ash fall on crops, infrastructure and water supply-and eruptions continue for up to one year [5]. A number of important settlements and 15\% of SVG's population are located in what are now classified as "very high-risk" and "high-risk" zones [6]. All these people would need to be evacuated in the event of volcanic unrest that suggested an imminent eruption, yet several towns in the very high- and high-hazard areas have recently benefited from investments in critical infrastructure, with further development planned for the future. This is based on a mix of "rational" planning logic (to reduce pressure on heavily populated areas in the south), equitable development concepts (to develop previously neglected areas in the north) [7] and party political motivations (stakeholders interviewed in this study claim the prime minister has favoured his constituency in the north).

Notwithstanding the political motives that may take precedence in physical planning decisions, identifying and pursuing a low-risk development strategy in volcanic SIDS presents a number of challenges. Even when authorities are aware of volcanic risk, there can be fewer options for reducing the losses associated with volcanic eruptions than for other types of hazards, beyond creating physical distance between the population and active centres. To compound this, active volcanic centres often yield the most attractive land for settlement and agriculture. For example, the distal runout from hazardous flows that provides flat land in otherwise hilly terrain or increased fertility in soils closest to active centres.

Monitoring and hazard assessment around these volcanoes is patchy (Table 1), with dedicated monitoring more often associated with islands that have seen eruptions in recent history. When an eruption occurs, and particularly if there are pyroclastic flows, disaster risk management (DRM) authorities respond by evacuating people, moving them out of harm's way and into shelters in the short term to reduce their exposure to the volcanic eruption $[15,16]$. Over the longer term, if activity persists, and particularly where there have been casualties, governments may seek to permanently relocate populations living close to volcanoes [15]. Long-term strategies are constrained, however, as typically $5 \%-20 \%$ of the population in volcanic SIDS live in the highest hazard zone, and in some instances this is even higher. Key infrastructure and even capital cities are often placed very close to eruptive centres (Table 1). 
Table 1. Volcanic small island developing states (SIDS) *.

\begin{tabular}{|c|c|c|c|c|c|c|c|c|}
\hline Country & Location, Size (1) & Population (2) & $\begin{array}{l}\text { No. Active } \\
\text { Volcanoes (3) }\end{array}$ & $\begin{array}{l}\text { Last Known } \\
\text { Eruption }\end{array}$ & Max ht. (m) & $\begin{array}{l}\text { Monitoring } \\
\text { System (11) }\end{array}$ & $\begin{array}{l}\text { Volcanic Hazard } \\
\text { Zones (11) }\end{array}$ & Population in High Hazard Zones \\
\hline Cabo Verde & $15^{\circ} \mathrm{N}, 4033, \mathrm{~A}$ & 498,987 & 2 & 2015 & 2829 & $\mathrm{Y}$ & $\mathrm{N}$ & $\begin{array}{l}\sim 12,000 \text { in collapse scar plane in Fogo; } 6000 \text { in Brava, } \\
44,000 \text { on pyroclastic plains in Santo Antão (4) }\end{array}$ \\
\hline Comoros & $11^{\circ} \mathrm{N}, 2034, \mathrm{~A}$ & 734,917 & 2 & 2007 & 2316 & $\mathrm{Y}$ & $\mathrm{N}$ & $\begin{array}{l}\text { 320,000 inhabitants on island with active volcano; } \\
\text { distributed settlements in highly active zone (5) }\end{array}$ \\
\hline $\begin{array}{l}\text { São Tomé and } \\
\text { Príncipe }\end{array}$ & $0^{\circ}, 1001, \mathrm{~A}$ & 192,993 & 1 & $\begin{array}{c}\text { Unknown } \\
\text { (settled 1493) }\end{array}$ & 2024 & $\mathrm{~N}$ & $\mathrm{~N}$ & $\begin{array}{c}\text { Entire population of São Tomé within } 30 \mathrm{~km} \text { of } \\
\text { volcanic centre (6) }\end{array}$ \\
\hline Dominica & $15^{\circ} \mathrm{N}, 50, \mathrm{~S}$ & 72,003 & 5 & 1270 & 1442 & $\mathrm{Y}$ & $\mathrm{Y}$ & Roseau (capital) in very high hazard zone (7) \\
\hline Grenada & $12^{\circ} \mathrm{N}, 344, \mathrm{~S}$ & 105,897 & 2 & 2015 & 840 & $\mathrm{Y}$ & $\mathrm{Y}$ & Chiefly coastal hazards from submarine volcano (8) \\
\hline $\begin{array}{l}\text { St. Kitts and } \\
\text { Nevis }\end{array}$ & $15^{\circ} \mathrm{N}, 176, \mathrm{~A}$ & 54,301 & 2 & 160 & 1156 & $\mathrm{Y}$ & $\mathrm{Y}$ & $\begin{array}{c}\text { St. Kitts main infrastructure in Zone } 3 \text {, coastal } \\
\text { villages in Zone } 1 \text {. Nevis, most settlements in zone } 1 \\
\text { (1 = highest hazard) (7) }\end{array}$ \\
\hline Saint Lucia & $14^{\circ} \mathrm{N}, 617, \mathrm{~S}$ & 182,273 & 1 & 1766 & 950 & $\mathrm{Y}$ & Y & 8472 live in Soufrière in highest hazard zone (7) \\
\hline $\begin{array}{l}\text { St Vincent and } \\
\text { the Grenadines }\end{array}$ & $13^{\circ} \mathrm{N}, 389, \mathrm{~A}$ & 109,373 & 1 & 1979 & 1324 & $\mathrm{Y}$ & Y & 23,000 live in highest hazard zone ( 7 ) \\
\hline Fiji & $18^{\circ} \mathrm{N}, 18,274, \mathrm{~A}$ & 881,065 & 2 & 1660 & 1324 & $\mathrm{~N}$ & $\mathrm{Y}$ & 14,500 on Taveuni (9) \\
\hline $\begin{array}{l}\text { Papua New } \\
\text { Guinea }\end{array}$ & $9^{\circ} \mathrm{S}, 462,840, \mathrm{~A}$ & $7,321,000$ & 53 & 2015 & 2715 & $\mathrm{Y}$ & $(\mathrm{Y})$ & $\begin{array}{l}15,000 \text { town near Rabaul, total evacuation of } \\
\text { Manam following activity in 2005; } 80 \% \\
\text { population within } 100 \mathrm{~km}(6)\end{array}$ \\
\hline Samoa & $14^{\circ} \mathrm{S}, 2842, \mathrm{~A}$ & 190,372 & 2 & 1911 & 1858 & $(\mathrm{~N})$ & $\mathrm{N}$ & Apia (capital) $12 \mathrm{~km}$ from Upolu (6) \\
\hline Solomon Islands & $9^{\circ} \mathrm{S}, 24,800, \mathrm{~A}$ & 560,685 & 9 & 2012 & 2332 & Y & $(\mathrm{Y})$ & Honiara (capital) $25 \mathrm{~km}$ from Savo (6) \\
\hline Tonga & $21^{\circ} \mathrm{S}, 748, \mathrm{~A}$ & 105,323 & 23 & 2015 & 1033 & $\mathrm{~N}$ & $\mathrm{~N}$ & Small populations on volcanic islands (6) \\
\hline Vanuatu & $17^{\circ} \mathrm{S}, 12,190, \mathrm{~A}$ & 252,763 & 11 & 2015 & 1877 & $(\mathrm{Y})$ & $\mathrm{Y}$ & $\begin{array}{c}\sim 45,000 \text { inhabit islands with most frequently active } \\
\text { volcanoes (10) }\end{array}$ \\
\hline
\end{tabular}

Notes: * These states are designated from the sub-set of UN SIDS that have one or more active volcanic centres (as defined by the Smithsonian Institution's Global Volcanism Program). (1) Latitude expressed to nearest degree of central point. Size is total island area in $\mathrm{km}^{2}$, A denotes archipelago nation (multiple islands), S single island; (2) Population data from World Bank dataset for 2013 [8]; (3) No. of active volcanoes and date of latest eruptions from the database of the Smithsonian Institution's Global Volcanism Program. Active is defined as volcano capable of further eruptive activity with activity recorded or inferred in the Holocene (last 10,000 years); (4) [9]; (5) [10]; (6) [11]; (7) [12]; (8) [13]; (9) [14]; (10) Vanuatu Geohazard Observatory; (11) Brackets in this category indicate partial or incomplete maps or incomplete monitoring, typically instruments without remote telemetry or monitoring of only some of the potentially active centres. 
SVG serves as a useful exemplar of the restricted options for reducing exposure and avoiding risk accumulation in volcanic SIDS. This paper starts by characterising volcanic SIDS, signalling the problem hazards present for growth and development, in addition to the problems of economic vulnerability that are more commonly presented in the literature. It then presents the options for managing volcanic risk in relation to development processes and decision-making. The volcanic context and methods section describes the impact of recent volcanic eruptions of La Soufrière in SVG and locates the areas most exposed to volcanic hazards, before going on to describe the approach to collecting and analysing data. We then assess the long-term development model adopted in SVG and efforts to reduce existing disaster risk, manage residual risk and avoid risk creation, with a particular focus on volcanic risk. We conclude by analysing the importance of risk-sensitive development planning and suggesting options for increasing awareness of, and resilience to, the volcanic hazard.

\section{Limits to Growth in Small Island Developing States}

There is a vast literature on development in SIDS, focusing on their special difficulties in terms of vulnerability, isolation and challenges for sustainable development [17-21]. Most papers focus on the economic and ecological fragility of these states relative to others. The literature has not explored in great depth their exposure to hazards as a major source of vulnerability and as a limiting factor for development, although there are some examples looking at specific hazards and communities (e.g., [22-24]).

SIDS are economically fragile because of their small size, insularity, remoteness and environmental fragility [25]. Size is considered a problem because it restricts options for development owing to limited natural resource endowments and means a small domestic market (and therefore constrained import substitution possibilities and/or high dependence on exports), dependence on a narrow range of products (over-specialisation) and limited ability to exploit economies of scale, thereby resulting in higher production costs $[25,26]$. Public administration systems are constrained by a lack of technical capacity and critical mass, as relatively low salaries mean specialist skills cannot be provided domestically or retained. Remoteness is a problem for some but not all SIDS, with transport costs higher than for countries with land borders. In addition, economic development places greater pressure on the environment in SIDS than it does in other countries, particularly where there is intensive use of coastal zones for tourism and marine activity [25]. These islands clearly face disadvantages compared with larger and non-island developing countries, and some scholars have noted that sustainable development may not be a feasible option for these small, very open economies [27].

SIDS are also very vulnerable to a range of environmental hazards $[20,25,28,29]$, and their small size and isolation compound this. Many are geographically remote and are consequently socio-economically and politically marginal [30,31]. They lack the institutions and systems needed to anticipate and cope with hazards, including effective early warning systems (EWS) and systems for managing evacuations and the distribution of basic relief support [32,33]. Vulnerability levels are high relative to other countries because of factors including low educational achievement, limited employment opportunities, difficult market conditions and restricted disaster recovery options $[15,18,28]$. In the Caribbean and elsewhere, lack of adherence to building codes and the use of sub-standard materials for informal construction exacerbate both exposure and vulnerability, as do high levels of poverty, socioeconomic exclusion and environmental degradation [34]. Inadequate air and sea transport links can often render evacuation difficult [35].

Understanding why levels of disaster risk are so high in SIDS also requires a detailed examination of the geography of these islands and, linked to this, the natural hazards themselves, as well as population exposure and vulnerability. Many SIDS-using the UN definition of SIDS but removing those that are not actually islands (Belize, Guinea-Bissau, Guyana and Singapore)-are located on or near plate boundaries, and they all are found within the tropics, defined as $23^{\circ} 26^{\prime} \mathrm{N}$ and $\mathrm{S}$ (bounded by the Tropic of Cancer and Capricorn) (Table 1 and Figure 1). Many owe their subaerial exposure to deposits from past volcanic activity, which results in a geomorphologically immature topography, 
with hills and mountain tops bounded by steep-sided, often unstable slopes. The volcanic SIDS are thus not only prone to storm surge and sea-level rise, in common with the other (more low-lying) SIDS, but are also susceptible to a wide range of geophysical hazards. The contrasting topographic characteristics of volcanic SIDS in relation to other SIDS mean the higher steeper volcanic islands are more prone to landslides (and earthquakes) and just as prone to hurricanes and flash-flooding as other SIDS. However, they may have more land that is removed from the impacts of storm surge and sea-level rise. The options for disaster risk-sensitive development in these two types of SIDS could be very different. In this paper we examine the development challenge posed by the first type: the steep volcanic SIDS.

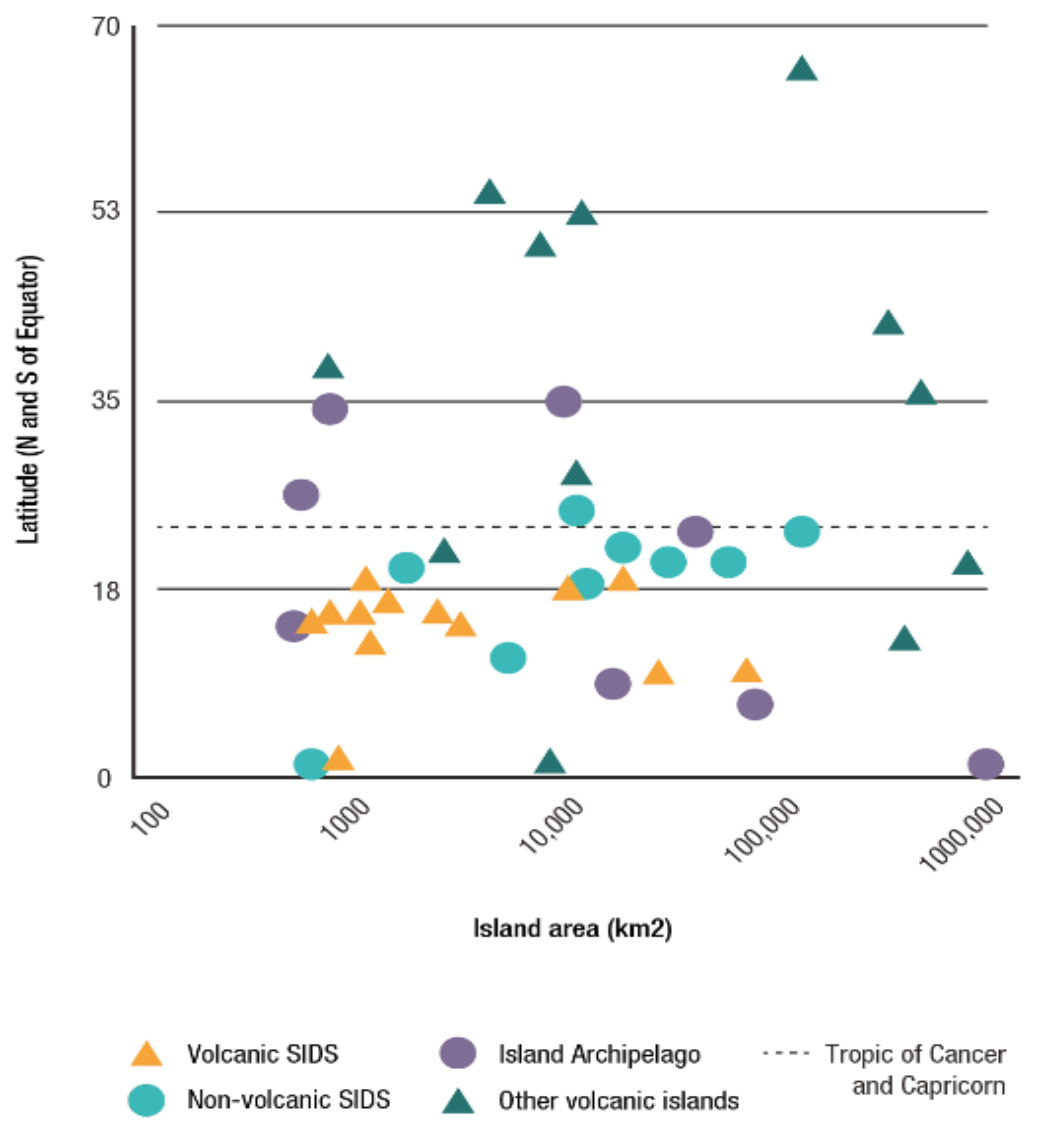

Figure 1. Islands nations of the world plotted by Latitude (in degrees North and South of Equator) and total land area $\left(\mathrm{km}^{2}\right)$. Dashed line represents the location of both the Tropic of Cancer and the Tropic of Capricorn.

\section{Exposure to Volcanic Hazards}

Volcanic hazards are multiple and interrelated, posing a complex set of challenges for DRM. Volcanic activity can be quiet and effusive or violent and explosive, and the length of time that an eruptive episode persists can vary from a few minutes to weeks, months or even decades [36]. Different hazards are associated with different types of eruptions, the most serious for those living in close proximity being pyroclastic flows and surges, tephra and projectiles. Other associated hazards include lava flows, atmospheric phenomena, volcanic earthquakes and phreatic explosions-although these tend to have a much more localised impact. Secondary hazards such as mudflows and landslides also pose problems for managing risk [5].

Sizeable proportions of the population live in areas exposed to mudflows and pyroclastic flows and projectiles (Table 1), and on many islands the entire population will be exposed to ash, even for a moderate-sized explosion. There is a tendency to build on low-lying land created by flows, closer to the 
coast. Some of the largest settlements are on debris fans. Often, areas exposed to the highest volcanic risk are the most attractive for economic development or are those where other types of environmental hazards can be avoided. Weathered volcanic rocks close to volcanoes provide fertile soils for farming, and volcanic debris can be used in construction. Volcanoes can be the basis for tourism, as is the case for many Caribbean SIDS.

The resilience of those exposed to volcanic hazards is highly idiosyncratic, but a distinction can be made between the short term, when there is elevated activity (or eruption), and the longer-term, when activity is prolonged and/or in recovery following a high impact event. In the short term, people are more resilient to volcanic hazards if they are able to receive and understand early warnings, know how to respond to these and how to evacuate, are able to protect their property and assets and can stay in shelters without suffering deterioration in their physical or mental health. This means monitoring systems and communications networks of all kinds need to be functioning well and preparedness planning needs to be robust, at both household and institutional levels. Volcanic eruptions can last for days, months and even years; hence evacuations also last for longer periods of time than they do for other hazards. Building resilience therefore requires action to avoid deterioration of health and assets over the longer term. Whether volcanic activity continues or not, the ability to rebuild and recover livelihoods without further depleting assets, as well as to learn and adapt policy and livelihood choices to minimise impacts in the future, is a sign of disaster resilience.

\section{Options for Managing Volcanic Risk}

Given the very serious implications of disaster losses for the current and future sustainable development of SIDS, there is a strong imperative for reducing disaster risk; however, reshaping development is complex and will require trade-offs. Governments are faced with different sets of challenges in their decisions on how to deal with disaster risk, including a lack of clarity on which are the most effective measures [37]. This is complicated by the fact that DRM requires both reducing risk that already exists and threatens development, and taking action to manage development processes in such a way as to avoid risk generation and accumulation in the future. Recent thinking on DRM suggests this needs to be understood in terms of three processes linked to development [4]:

1. reducing existing risk;

2. avoiding the accumulation of new risk;

3. building resilience of people and societies to residual risk that cannot be effectively reduced.

Volcanic SIDS have limited options for reducing existing risk. Arguably, the best option for preventing immediate loss of life and property from pyroclastic flows and lahars-the most intense and highest impact hazards - is through removal of people and their assets from areas exposed to these hazards. Structural measures that might be useful for earthquakes, such as sound structural engineering, would be generally ineffective for zones at risk from lava flows. In contrast, in zones further removed from eruption centres, designing roofs that prevent heavy ash accumulation is an option [38]. Other options to mitigate the impacts of lahars include Sabo dams and careful house construction. Cleared drainage channels can help reduce the impacts of lahars on property and also mitigate against climate change and intense rainfall outbursts. Relocation schemes have often been used to minimise exposure to volcanic hazards. In Montserrat, the UK government and local authorities endorsed the permanent relocation of communities from areas affected by the 1995-1997 eruption and imposed an exclusion zone to discourage people from returning [39]. Yet such initiatives have often increased people's exposure to hurricanes and other hazards. It is not uncommon for relocated people to return to the hazardous evacuated areas when their tolerance of volcanic risk increases relative to other risks, or in search of better livelihood options [38,39].

Avoiding the accumulation of new risk is also critical but particularly problematic for volcanic SIDS. Exposure to hazards and the potentially devastating impact of disasters on their economies and citizens makes it imperative that SIDS prioritise risk assessments in physical development and land-use 
planning and ensure building codes are appropriate to the multi-hazard context. The development of capacity in risk analysis and mapping as well as in the application of the results to development decisions is therefore a critical component of support to DRM [40]. How these assessments are conducted and the knowledge that is incorporated are also of importance: participatory approaches to risk analysis are often recommended, as well as the integration of scientific and local/traditional knowledge to inform planning decision-making and implementation [41,42].

Building resilience to residual risk is interpreted differently by scholars but is often used to refer to the capacity to anticipate and cope with shocks and stresses in the short term and to recover and adapt livelihoods and systems over the longer term $[43,44]$. Among the most effective measures available to governments to minimise losses, particularly from the more intense volcanic hazards (pyroclastic flows, lahars, explosions), preparedness planning and Early Warning Systems (EWS) are found to "require little in the way of complex (re-) construction (and) are likely to be both comparatively cost-effective and institutionally simple" [45] (p. 24). In recent years, efforts to help people anticipate and cope with volcanic hazards have focused on improving monitoring networks and the accuracy and timeliness of early warnings; increasing public awareness; working with communities to ensure messages are communicated, understood and transmitted effectively; enhancing personal prepared ness planning; and securing evacuation routes and the provision of adequate and safe shelters [11]. Measures that build longer-term resilience to volcanic hazards, particularly the low-intensity ones, include livelihood adaptations and alternatives. These adaptations are based on traditions and lay knowledge and monitoring of the hazards [46,47], as well as having access to-and control of-natural resources and using these in a sustainable way [38,47].

This paper examines land-use and physical planning options in SVG and how these could include information from risk assessments more systematically, even within the spatial constraints of a small island (when space for development is very limited). By paying greater attention to options that build resilience to multiple hazards, a more risk-sensitive development model can be pursued.

\section{Volcanic Context and Methods}

SVG is situated within the chain of islands known as the Lesser Antilles Volcanic Arc. Some of the highest relative levels of exposure to volcanic hazards are found in these islands: in St Lucia, St Kitts and Nevis, Dominica, Montserrat, SVG and Grenada, over $90 \%$ of the population is exposed to some kind of volcanic hazard, including ash [4]. SVG's La Soufrière volcano is one of the most active in the region [5].

SVG has suffered a number of destructive disaster events, including an eruption in 1902 that killed 1565 people and produced losses calculated at $\$ 49,536$ of land $(24.5 \%), \$ 51,200$ of produce $(25.4 \%)$ and $\$ 34,560$ of earnings (17.1\%) (Her Majesty's Stationery Office 1903, in [5] p. 176). The eruption was preceded by 12 months of earthquake activity and characterised by pyroclastic flows, mudflows and ash fall, affecting areas to the north-east, east and west of the volcano [5]. Several damaging hydro-meteorological events have occurred in more recent years, including a storm in 1955 that killed 122 people and storms with flooding in 1980, 2010 and 2013 with fewer casualties but damages of at least $\$ 16.3$ million, $\$ 25$ million and $\$ 108$ million, respectively [48]. In 1971, a small effusive, dome-building eruption occurred. Populations were not affected but communities in the north of the island were evacuated [5] (p. 186) (the author posits that these evacuations likely owed to concern prior to an election rather than being a response to scientific advice). Eight years later, on 13 April 1979, a larger magnitude explosive eruption resulted in 20,000 residents being evacuated from within a 10-mile radius of La Soufrière. The eruption had a major economic impact on agriculture, in particular in terms of loss of bananas (which represented approximately $50 \%$ of export earnings at this time) and livestock.

We used a mixed methods approach to study DRM and development in SVG, and in particular how volcanic risk is understood and incorporated in DRM and development planning decisions. Data were collected from a number of different sources and triangulated. This included semi-structured 
interviews with government officials and community leaders; scenario exercises with planners from different departments; household surveys applied in very high- and high-hazard areas close to the volcano; and public and private investment data for areas close to the volcano. Questions across all data sources explored risk perceptions and how volcanic risk is being considered in efforts to reduce risk, in emergency preparedness and response and in longer-term planning decisions (to avoid creating new risk). Data collection was carried out in a number of field visits between January 2014 and December 2015.

A total of 50 semi-structured interviews were conducted with governance stakeholders at three different levels: community level, with community representatives or leaders working on some aspect of DRM; national level, including government officials and representatives of national civil society organisations; and representatives of regional and international agencies involved directly in projects in SVG, or in collaboration with other partners working in SVG. The interview questions centred on perceptions of volcanic risk, disaster impacts on sectors, the extent and effectiveness of measures adopted to manage risk since 1979 and options for more effective DRM in the future. Interviews were recorded, transcribed and coded using Atlas-ti. Codes developed for each theme were analysed for each stakeholder group, allowing for triangulation between different accounts.

The household survey was conducted with a sample of 400 households in two hazard zones: very high risk (red zone) and high risk (orange zone) (see Figure 2), with a stratified sampling strategy designed to cover a continuous area in the north of the island, comprising most of the red hazard zone and some key settled areas in the orange hazard zones. The surveyed areas correspond to three census districts: Sandy Bay in the far north (in the very high-hazard area); Georgetown on the north-east coast (those surveyed are in the very high-hazard area, although the census district is divided across the very high- and high-hazard areas); and Chateaubelair in the north-west (high-hazard area). The total household population of 2617 across the selected enumeration districts formed the sampling frame. The sampling area was also designed so the Sandy Bay census division (far north of the island) formed a minimum of one-quarter of the total sample size (25.3\%), and the leeward (western) side formed a minimum of one-third of the sample (36\%).

The survey questions mirrored those in the semi-structured interviews, focusing on changes in the integration of volcanic risk in decision-making from the perspective of those living close to the volcano. However, given the limitations of recall methods, the decision was taken to include only questions with regard to two types of changes that would be likely to stand out in people's minds: access to services and responses to disasters. Respondents were asked about their access to different services in the 1980s, the 1990s and today; and about things that happened before, during and after the 1979 eruption, Hurricane Tomas in 2010 and the floods on Boxing Day 2013.

To complement the semi-structured interview data and explore in greater depth how one particular hazard was considered in sectoral planning decisions, maps of ash fall impacts (based on a 1902 eruption scenario) were discussed with planners in different departments within the Ministries of Agriculture, Forestry and Fisheries; Education; Transport, Works, Urban Development and Local Government; and Housing. The exercise involved showing ash fall maps to the planners with contours marked in different colours, delimiting areas where volcanic ash could have a greater or lesser impact on infrastructure and agriculture. 


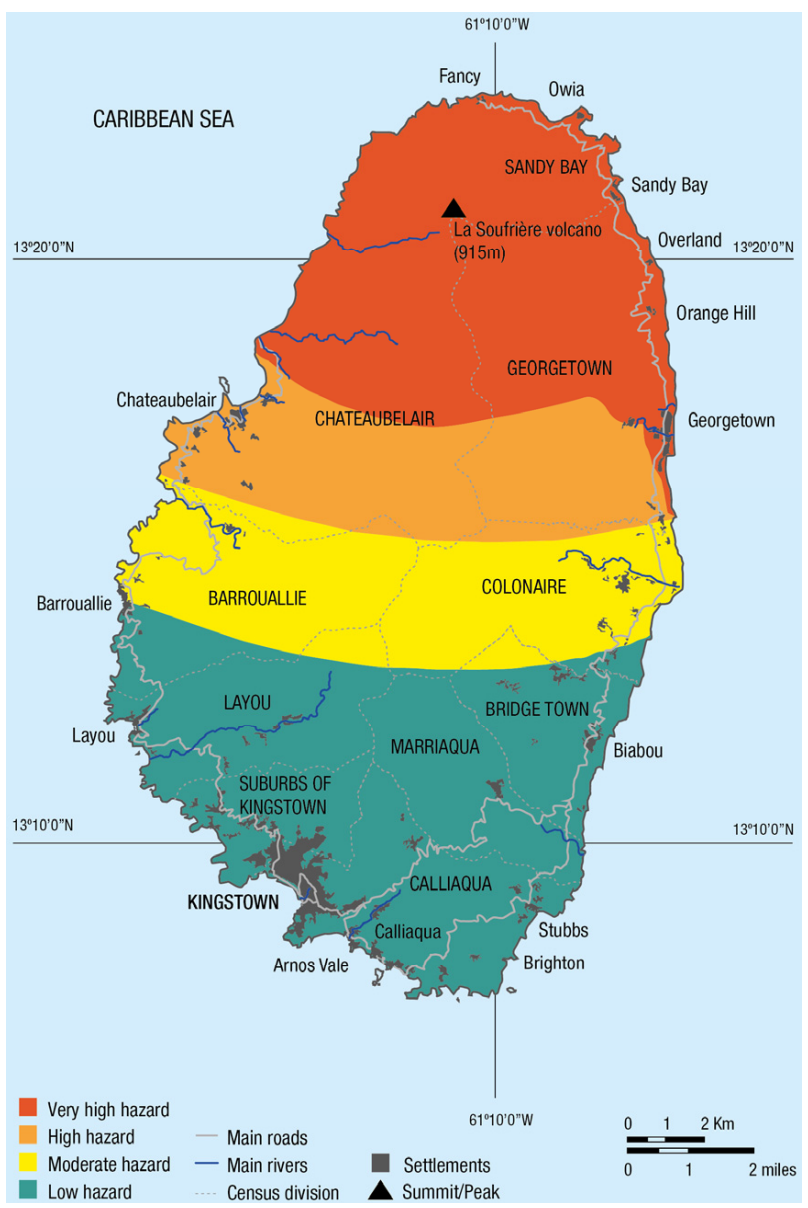

Figure 2. Integrated volcanic hazard zones, 2014. An alteration to the volcanic hazard map was made in 2014. The previous version had one small area in the north of the island in the "orange" rather than the "red" zone. This was based purely on consideration of the hazard. Given that once an eruption started it would be difficult to get people out of this area to safety in the south, the decisions was taken to include this within the red zone. Also, the designation of this area as "orange" presented an impression of relative safety that would have made it difficult to mobilise the population in the event of future eruption. Source: Adapted by the University of the West Indies Seismic Research Centre following discussions with National Emergency Management Organisation.

\section{Geographies of Risk and Development in St Vincent and the Grenadines}

The eruptions of La Soufrière volcano in St Vincent in 1902 and 1979 have had a lasting impact on the population. Before 1902, the destructive potential of the volcano was not fully realised. No monitoring system was in place and scientific knowledge of the system was very limited. This perception changed after 1902, and subsequent events have led to significant improvements in the monitoring network [49]. Despite greater awareness of volcanic hazards and their impacts, however, the population living in the three census districts closest to the volcano has remained fairly stable. After the 1979 event, people returned to their homes and previous activities. In total, $83 \%$ of evacuated survey respondents reported returning to the same place after the eruption.

Close to $15 \%$ of the population of SVG today lives in the very high- and high-hazard areas on the volcano hazard map (based on 2012 population data for the Georgetown, Sandy Bay and Chateaubelair districts). According to the work of Boruff and Cutter [28], the size of the population exposed to volcanic risk in SVG is second only to that exposed to landslides, with an estimated $78 \%$ of the population at risk; only $4 \%$ of the SVG population lives in flood-prone areas. However, a recent, more 
detailed, analysis of hazards on behalf of the World Bank reveals a greater susceptibility to landslides, a larger population exposed to flooding and a significant threat from coastal erosion [50].

While this separation of hazards is convenient for analytical purposes, the reality for risk-sensitive development planning is more complex. A good example of the intrinsically linked nature of geophysical and hydro-meteorological hazards is the December 2013 flood event, which happened just before the start of the research visits through 2014 and 2015. This intense rainfall event recorded $109 \mathrm{~mm}$ of rainfall in the 12-24 h between 23 and 24 December, killing 12 people and displacing 2325 [51], many of these in the very high- or high-hazard zone. During the intense rainfall from an unusual low-level trough system, loose sediment on the volcanic slopes affected residential areas not historically known to be flood-prone (based on observations of government officials interviewed in July-August 2014). This resulted in landslides, choked waterways and diverted debris-laden flood waters. Landslides are common in SVG and are closely linked to seismic and volcanic activity as well as heavy rains. They destabilise slopes and contribute to debris-laden runoff. Although the triggers differ, the impacts are similar. These include the flooding and choking of natural and built drainage systems after heavy rains, as witnessed in December 2013. Poor solid waste management practices (littering) and blocked drains make this situation worse, particularly during the hurricane season. These connections between hazards suggest an integrated approach to DRM may be more effective than trying to deal with them separately.

Before the eruption of 1902, the population of SVG was dispersed through the country, with many workers on the large estates in the north of the country, including areas that now fall within the very high- and high-hazard zones. Georgetown was an important economic and population centre under British rule, but economic activities were in decline and poverty rates high because of a struggling sugar industry and neglect by absentee landlords. The UK government responded with a Road and Lands Settlement Fund [52]. Much of the indigenous population also resided in the very high-hazard zone, having been pushed onto increasingly marginal land as a result of the development of large plantations through the 19th century. The focus of this was the acquisition of land to encourage smallholdings, livelihood diversification and the improvement of infrastructure, but its dispersal was interrupted by a hurricane in 1898 and the volcano in 1902 [52].

An evacuation line was created after the 7 May 1902 eruption, extending from just north of Barrouallie in the west to just south of Colonaire on the east coast [53]. New settlements were established to accommodate evacuees, but considerable numbers moved to Kingstown, and refusal by the authorities to use the Mansion House Eruption Fund (created by the UK government with multiple individual and governmental donations) to compensate plantation owners in the high-hazard zones for their loss finally resulted in landowners selling their land [52]. The volcano therefore effectively removed much of the economic activity and surrounding population that had contributed to the vitality of Georgetown as a population centre.

Regional development is back on the agenda in SVG, but being directed by national government after a failed attempt at devolution. Under the 1951 Local Government Act, local government authorities were established in the main population centres outside of Kingstown, but these were imbued with limited authority [54]. Local government was dissolved in the 1970s but, following independence in 1979, the Local Authorities (Termination of Dissolution) Act of 1981 restored some power to local government. Today, local government is an administrative mechanism for effecting central government direction and authority in a limited sphere of activities. Parliament has debated the reintroduction of local government, but a referendum held in 2009 proposing replacing the monarch with a non-executive president was defeated, and along with it a proposal to include local government in the Constitution [55].

Today, approximately $50 \%$ of the population of SVG lives in the capital Kingstown, the surrounding neighbourhoods and the port area of Calliaqua, all of which are in the south of the main island of St Vincent. The population in Greater Kingstown has grown rapidly in the past 30 years owing to internal migration, with an increasing number of people looking for employment 
opportunities, better education, housing and overall social mobility in these highly populated areas. The north of the island, meanwhile, has experienced a decline in the rural economy [7] (pp. 30-31).

Agriculture continues to dominate the north where soils are fertile owing to their volcanic origin, but earnings from agriculture (not taking into account earnings from illegal marijuana farming, which may have increased) have declined in recent years. There are a number of reasons for this, including loss of preferential status for banana exports into Europe in the 2000s and the impact of meteorological hazards and crop diseases [56]. Economic diversification has been sought, as well as the diversification of agriculture; efforts to develop the services sector have focused on tourism and finance [56], with growth in hotels concentrated in the Grenadines [57].

Development in and around Kingstown has been largely a process of unplanned spatial growth and the expansion of secondary and tertiary economic activities, including government administrative services. The concentration around Greater Kingstown is creating pressure on land space, basic services, infrastructure and transport systems, as well as limiting employment opportunities available in the area. Squatter settlements are growing on marginalised peri-urban land prone to landslides and flooding. Overall, increased congestion in the Kingstown area, along with population losses and "further stagnation" in the northern areas, underscores the very limited development options and economic opportunities available on the island.

In response to these pressures, the Draft National Physical Development Plan [7] outlined four options for growth:

1. continuing along the existing trend (with increased development in the Kingstown area);

2. dispersal (decentralisation diverting growth from areas of concentration to areas that are declining);

3. dispersed concentration (development channelled in selected areas where potential exists for self-sustained growth);

4. planned concentration (a variation of the current trend, with an attempt to derive an efficient development form to accommodate existing development patterns).

All of the strategies assume a continued emphasis on agriculture, and efforts to diversify this sector beyond banana crops, as well as the diversification of the wider economy by encouraging the development of other sectors, particularly resort tourism [7] (p. 98).

According to one town planner, the strategy of "dispersed concentration" was believed to offer the greatest opportunities to help slow the rapid growth in Kingstown, and for environmentally, economically and socially sustainable development in SVG. This option sees continued development in Greater Kingstown, while at the same time developing and building up other regional growth centres [7]. The strategy targets selected settlements for development and upgrading of infrastructure and services to "assist in meeting social equity objectives by spreading development into neglected rural areas". Factors determining site selection include level and quality of existing infrastructure and services, potential for upgrading and improvement and the capability of the settlement to sustain growth, plus the availability of land with development potential. Avoiding agricultural land and ecologically sensitive areas is mentioned, but not hazardous locations. Georgetown is considered the only settlement in the country, outside of Kingstown, that would meet most of these requirements, with Calliaqua, Layou, Barrouallie and Chateaubelair also being options. Georgetown also lies within the prime minister's constituency of North Central Windward, and many stakeholders believe the investment focus there is politically motivated.

Of the five centres identified, Georgetown is the only one located in the very high-risk zone (see Figure 3). The government has recently made some important investments in Georgetown, building a modern medical complex, with a diagnostic centre that will take dialysis. Since 1980 road improvements have been a priority (approximately $\$ 23.5$ million between 1980 and 1999, and \$59.1 million since 2000 of public and private investment), but social infrastructure investments in schools, hospitals, water and sanitation have been even more substantial (\$28.9 million from 1980 to 1999; \$59.4 million since 2000). Other major public and private investments in the Georgetown area 
include coastal defence projects (approximately $\$ 5$ million since 2013) and economic infrastructure to support fishing, horticulture and tourism (\$7.5 million from 1980 to 1999; \$19.7 million since 2000). (All figures have been converted from Eastern Caribbean dollars into British pounds at an exchange rate of 1:0.26. They have been adjusted for inflation at December 2015 values. Documents consulted to collect investment data include "Estimates of Revenue and Expenditure: 1979 to 2015"; "Government Gazettes: 1979 to 2015"; "Ministry of Transport and Works Inception Reports: 1979 to 2015"; and the National Library and Archives Department, SVG.).

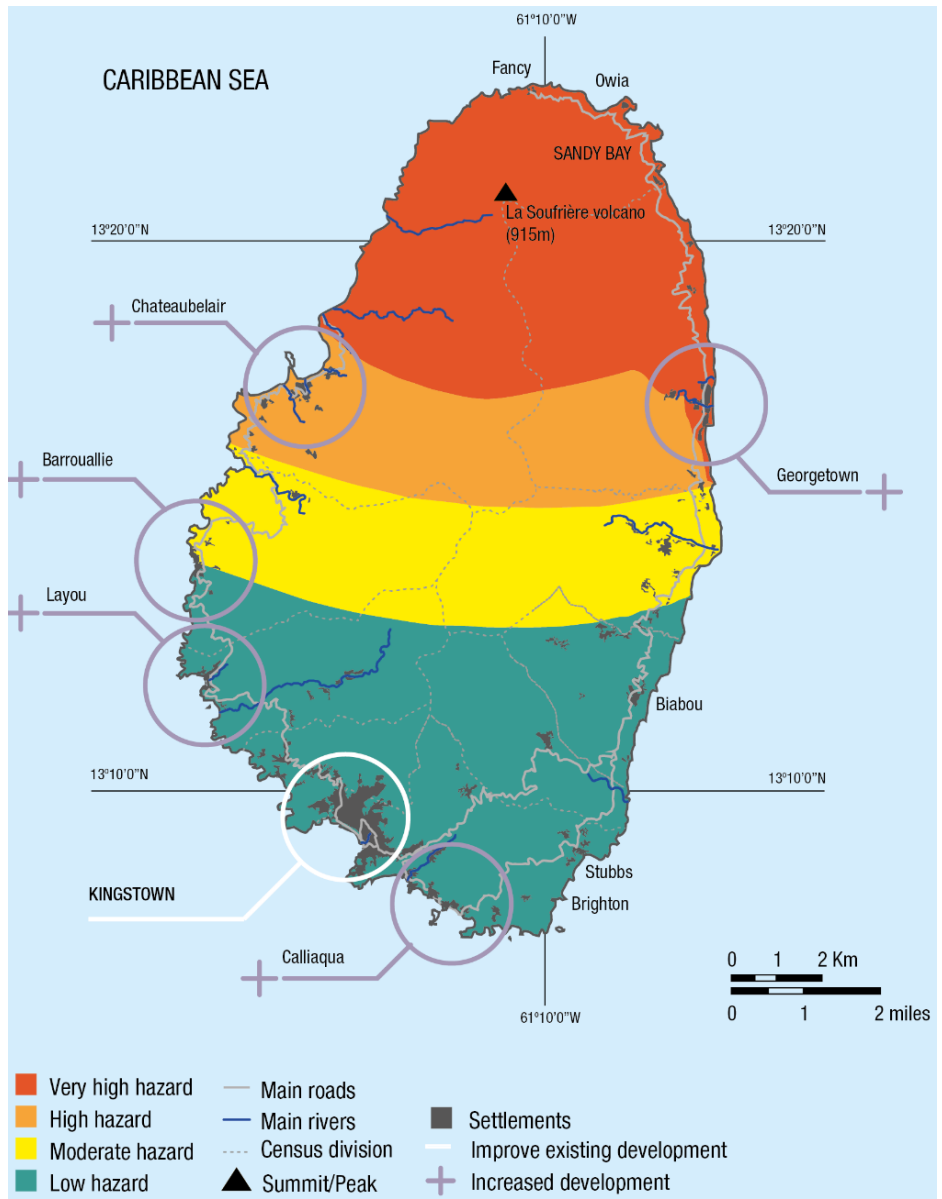

Figure 3. "Dispersed concentration" option in the Draft National Physical Development Plan [58]), with plans for increased development in very high- and high-hazard areas.

Further investments are being planned for Georgetown, including more banks and economic infrastructure. According to one town planner, this will result in a more balanced distribution of resources across the country and, "Once the economic situation has been resolved, Georgetown could even be restored to its former glory" (21 January 2014).

Census data confirm that populations located close to the volcano have benefited from these investments. Close to $100 \%$ of all survey respondents in Georgetown and Sandy Bay in the very high-hazard zone and Chateaubelair in the high-hazard zone have access to almost all basic services (see Figure 4). Electricity and secondary education have seen the most important changes since 1979. 

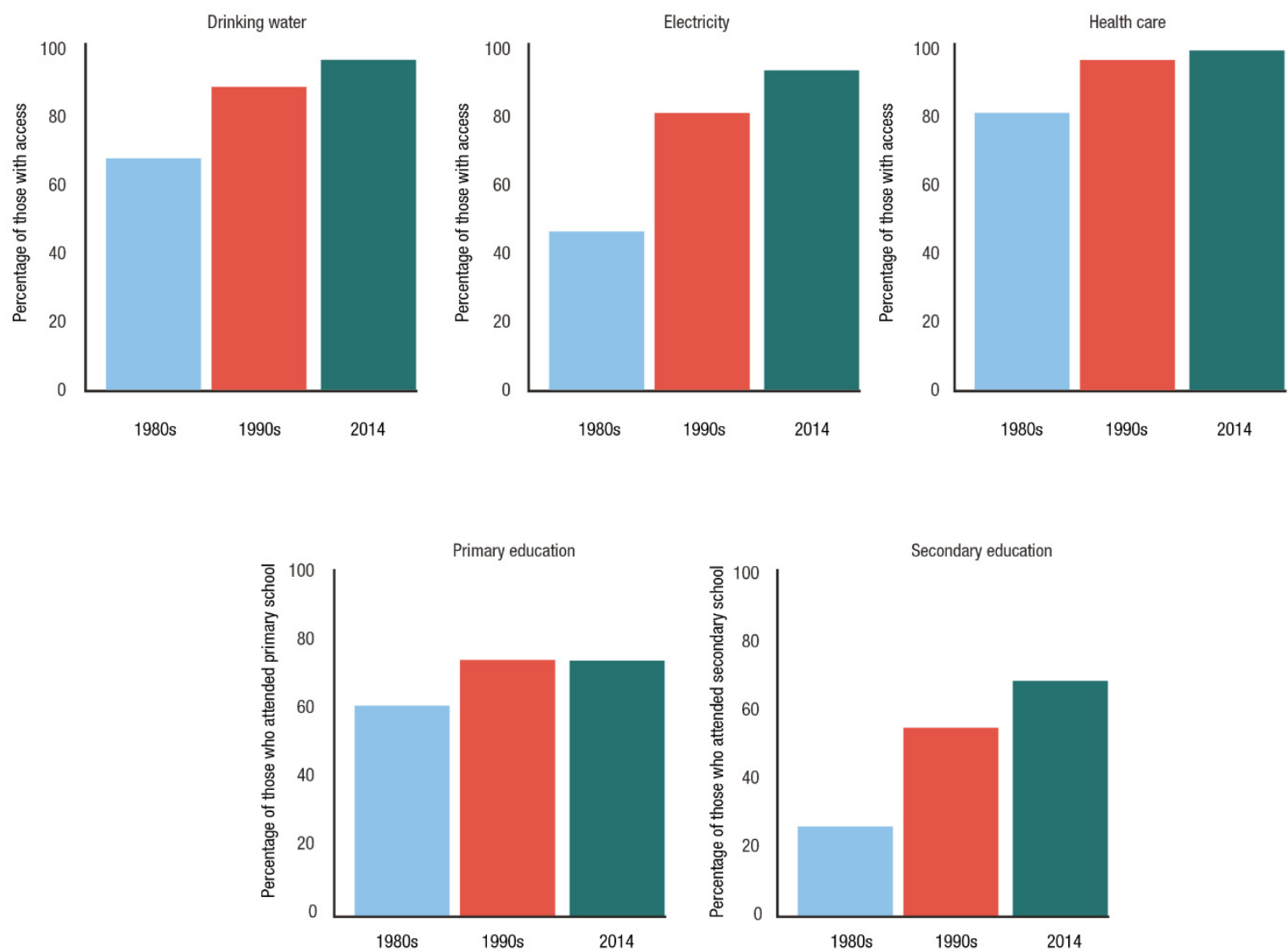

Figure 4. Access to basic services among survey respondents in very high- and high-hazard areas (\%).

The small settlements of Fancy, Sandy Bay and Owia in the very far north of the island include indigenous Carib communities that have been marginalised socially and economically from development in the south. Recent investment in these remote settlements is designed to compensate for years of neglect, although decision-making about how resources are allocated remains centralised in Kingstown.

\section{Disaster risk Management in St Vincent and the Grenadines}

The National Emergency Management Organisation (NEMO), established under the National Emergency and Disaster Management Act 2006, is responsible for coordinating DRM in SVG [57]. NEMO comprises a National Emergency Council, a National Emergency Executive and district disaster management committees. A Secretariat oversees day-to-day management of the national DRM programme and coordination of response operations. These activities focus primarily on building short-term coping capacity, as described below.

Reducing volcanic risk. Data from semi-structured interviews and surveys conducted in SVG confirm that efforts to reduce disaster risk have been limited in scope and effectiveness, focusing mainly on landslide and flood risk. There are many projects funded by international and regional development partners through grant and loans (including the Caribbean Disaster Emergency Management Agency (CDEMA), the Pan American Health Organization (PAHO), the UN Development Programme (UNDP), the Caribbean Development Bank (CDB), the Caribbean Community and Common Market (CARICOM) and the Organisation of Eastern Caribbean States (OECS)). These focus on structural mitigation measures such as slope stabilisation, drainage improvement, river training and road rehabilitation, in addition to capacity-building in hazard and risk evaluation, project management, public education and awareness-raising and modelling climate change risks. These actions also help reduce risks associated with volcanoes, although volcano-specific mitigation measures are not described in the 
development planning or policy documents reviewed by the authors. Only the National Economic and Social Development Plan 2013-2025 [59] mentions DRM, with an objective of improving preparedness, response and disaster mitigation capacity. There is no mention of volcanic risk.

The planning officials who took part in the ash fall scenarios exercise recognised that different services, infrastructure and livelihood activities would be affected by ash, including agricultural practices, crops, irrigation and household water supply, hydropower plants located in the north and electricity and power lines. One of the planners even suggested power lines could be placed underground to protect them from ash. However, in none of the conversations did planners reveal actions that had already been taken to mitigate these impacts.

Avoiding creation of risk in the future. Avoiding the creation of risk presents perhaps the greatest challenge for SVG. Building and land-use regulations are difficult to enforce, with new buildings continuing to go up without planning permission in flood-prone areas near to the coast. As one developer admits, "I know the Planning Unit in St. Vincent is strengthened to verify things are being approved and implemented. But I can't say it has been done in every case. ... If I want to build a big house and I get approval to build a big house then I may not look on structural integrity and construction because my builder says you can get away with that, you don't have to worry about what those engineers says" (20 August 2014).

People were moved out of high-risk areas into safer locations after the 2013 floods when houses were damaged or destroyed, but the government has not prohibited further development or demolished the houses left behind in these places. In the past, people have moved on to marginal land after a disaster has occurred, unaware of the risks, as one resident described: "It's kinda hard to regulate people leaving some nice land, somebody gonna squat there ( . . . ) I mean 20-25 years nobody gonna remember that there was a flood there some people lost their lives there" (20 August 2014).

A number of interviewees highlighted that risk assessment, monitoring and analysis of disaster risk were not a requirement in project planning or implementation, and one official in the Ministry of Finance and Economic Planning noted that the scientific basis for decision-making was generally weak. An interviewee in the Ministry of Housing felt risk maps could be really useful for avoiding the accumulation of new risk by restricting development that takes place in those areas: "What is there is there already, we will have to just live with that, but we can restrict it from this point on" (17 June 2014). In terms of the new developments in Georgetown, an official from the Ministry of Housing explained, "We have to take the gamble-we decided to build it. It may be destroyed, who knows when. Not sure if a risk assessment was carried out" (17 June 2014).

In the ash fall scenario planning exercises, planners from different ministries recognised to varying degrees the trend towards increasing physical development in the north, and the need to be aware of different scenarios. Ash fall scenarios have not been used in long-term development planning to date, but there was one concrete example of incorporating this risk into building design: PAHO recently installed a solar panel at a hospital in Georgetown, which was angled so volcanic ash would not cover it in case of an eruption. Overall, participants in this exercise felt volcanic risk information would be useful as a tool to guide planning and policy.

Building coping capacities of exposed communities. Strategies aimed at protecting the population by increasing their capacity to prepare and respond to early warnings in the short term, when volcanic activity is detected, are the most clearly defined in SVG. Far fewer options for building the adaptive capacity of communities living close to the volcano have been considered in SVG planning documents. Notably, all DRM plans are emergency or disaster management plans, not risk management plans. The National Volcano Emergency Plan (NVEP) (an Annex of the National Disaster Plan 2005 [58]), the National Disaster Plan (focus on preparing communities to react promptly to save lives and protect property) as well as the National Emergency and Disaster Management Act No. 15 (2006), the Emergency Powers Act No. 45 (1970) and the Natural Disaster Relief Act (1947) all guide the activities of NEMO in SVG. 
For scientific and technical support in managing the volcanic hazard, NEMO depends on the University of the West Indies Seismic Research Centre in Trinidad, which is responsible for monitoring the La Soufrière volcano in collaboration with the Soufriere Monitoring Unit, which is part of the Ministry of Agriculture in SVG. Since 1979, interviewees agreed, there have been significant improvements in hazard monitoring, interpretation of monitoring data and the development of an EWS. Yet one official noted that the challenge for emergency response is not only having an EWS in place but also "ensuring people are sufficiently educated as to how to respond to these early warnings" (21 August 2014). The last simulation and evacuation exercise for a volcanic eruption took place in 2003. Thirteen years later, people may not remember much of this exercise and the younger population will not have received any training on how to evacuate. Another interviewee highlighted that the evacuation plan "needs to be better articulated", that it is "still premature in terms of its design" (21 August 2014).

Evacuations are a particular challenge in SVG because of limited road networks as well as the steep winding nature of roads and their poor quality in some places. While road infrastructure has improved, one concern mentioned by several officials is that, in contrast with 1979, the government no longer owns trucks that could assist in evacuation. In addition, car ownership has increased significantly in SVG (from 2000 vehicles in 1979 to approximately 20,000 today). This presents serious problems in terms of congestion. NEMO is paying more attention now to improving communication and awareness of volcanic hazards, working with the SVG Red Cross to conduct vulnerability and capacity assessments and simulation exercises and to develop contingency plans. Further work is needed in this area, as $91 \%$ of survey respondents said they did not have any kind of emergency plan.

Survey respondents in the very high- and high-hazard areas had some knowledge of actions taken to manage volcanic risk (Figure 5). The largest response grouping recognised the role that improved warnings had played, with considerably fewer providing answers that could be related to improved infrastructure (better roads or shelters).

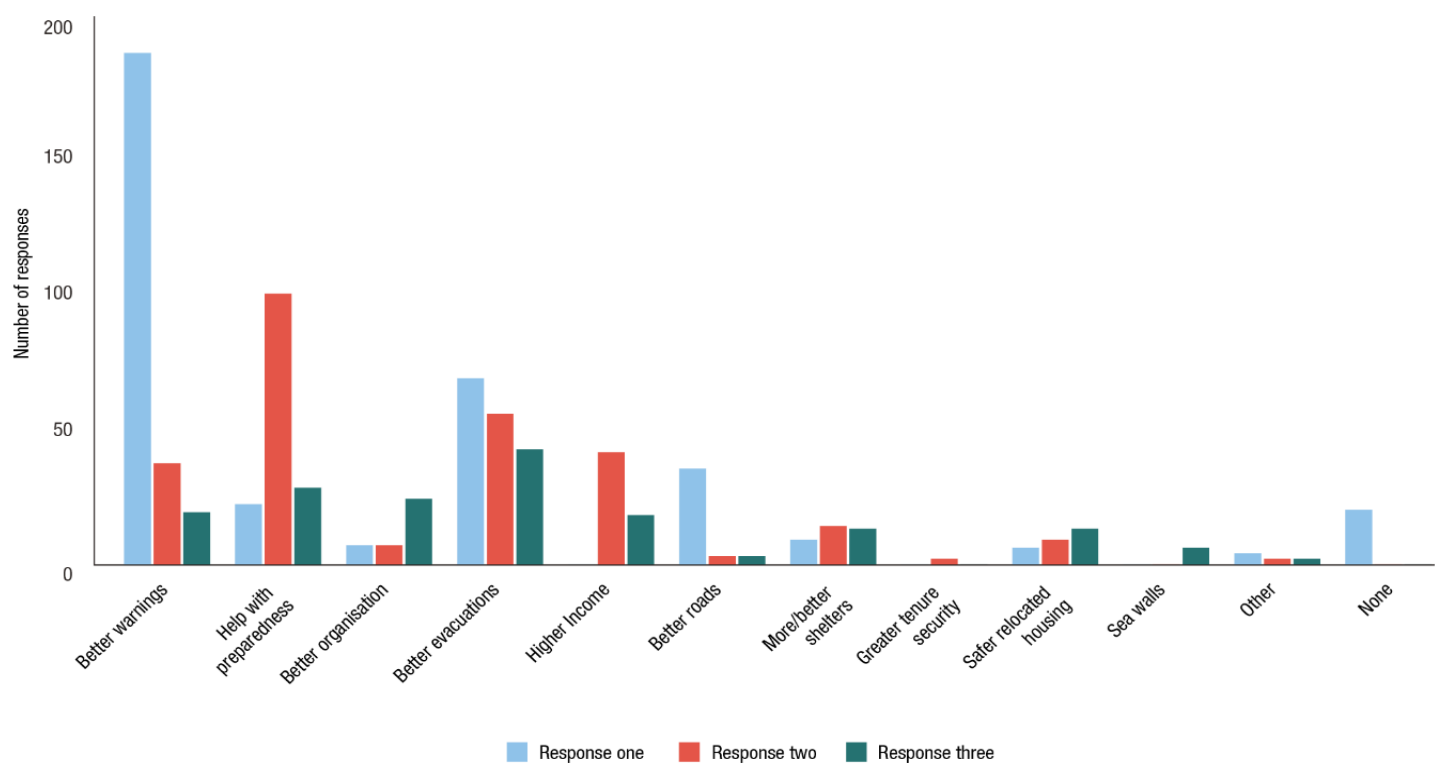

Figure 5. Top three responses to multi-response question on what improvements have been made in the past to make people less vulnerable to hazards. Respondents were able to provide up to three choices from 12 options (and provide their own response). A total of 358 out of 401 interviewees provided at least one response and 169 provided three responses.

When asked about the changes needed to reduce the impact of storms and volcanoes in the future (Figures 6 and 7), there were fewer responses for volcanoes than there were for storms. Nonetheless, the fact that well-organised evacuations featured in $22 \%$ of answers shows respondents had some 
awareness of issues around volcanic eruptions. With regard to storm impacts, respondents focused more on reducing exposure, with $34 \%$ considering housing relocation to safer areas as the best option, $21 \%$ "better warnings" and 23\% "help with preparedness" or "other" as useful.

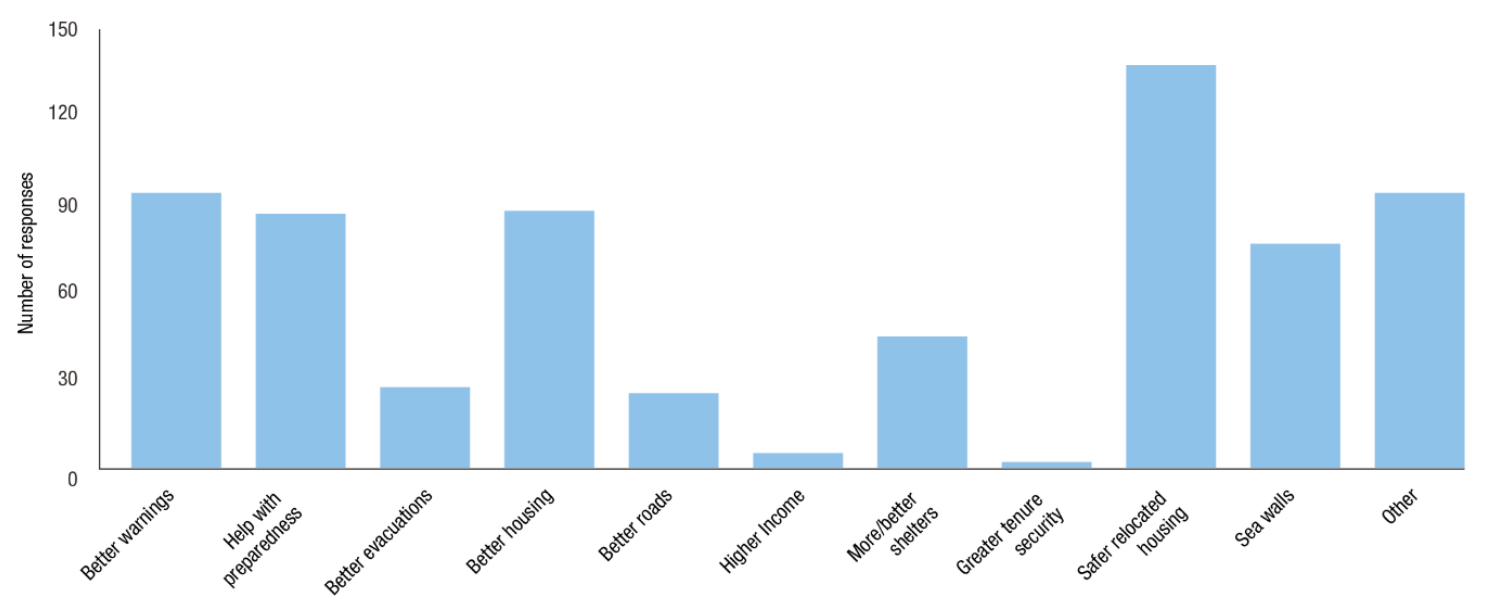

Figure 6. Response to survey question on what more needs to be done to reduce the impact of storms and heavy rain in the future. Respondents were encouraged to select up to three answers from 12 options, including a free choice. Each option has a maximum response rate of 401 (if all respondents supplied that answer as one of their chosen three). The number here shows the total number of respondents who selected that option as any one of their choices.

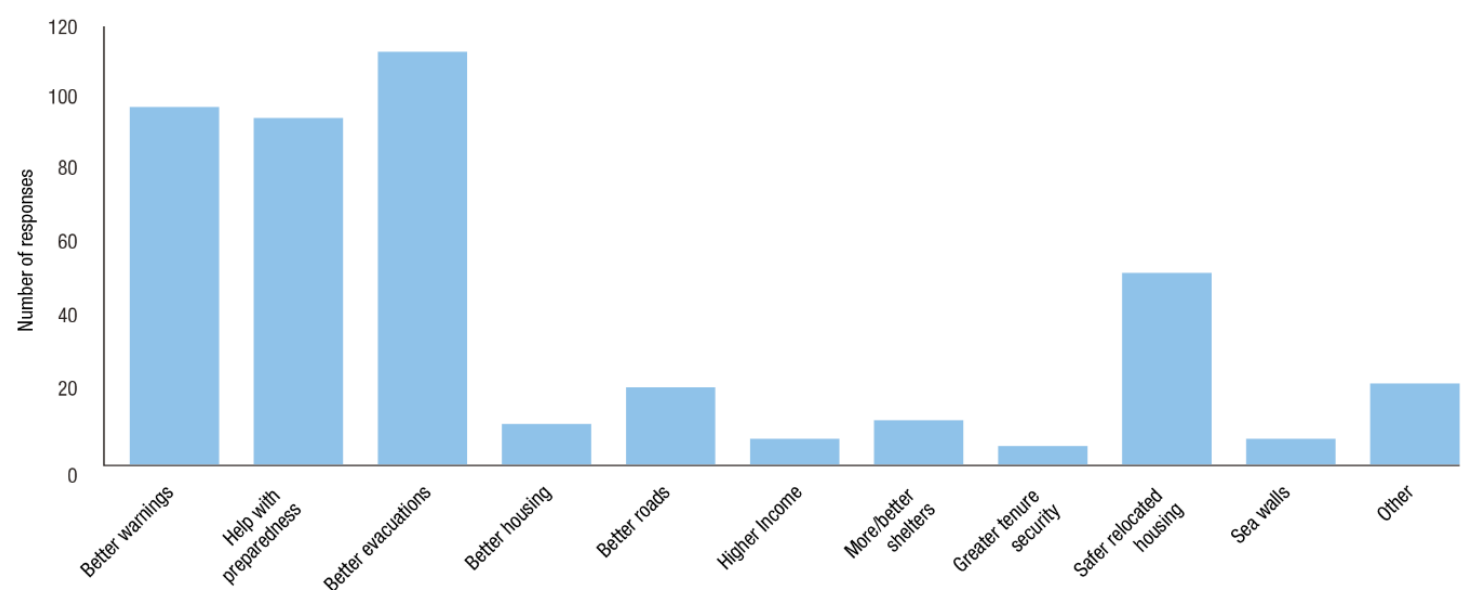

Figure 7. Response to survey question on what more needs to be done to reduce the impact of volcanic eruptions in the future. Respondents were encouraged to select up to three answers from 12 options, including a free choice. Each option has a maximum response rate of 401 (if all respondents supplied that answer as one of their chosen three). The number here shows the total number of respondents who selected that option as any one of their choices.

Overall, analysis of the various measures undertaken to manage disaster risk in SVG suggests that volcanic risk is not a priority and little will be done until volcanic activity increases. A few planning officials and a minority of those living close to the volcano felt that volcanic risk could be reduced and avoided in the future through relocation of infrastructure and housing and better land use planning, but these views are not reflected in official plans or DRM activities. There is considerably more interest however from both those living close to the volcano and government officials in strengthening capacities to respond effectively in the event of an eruption. This alignment of views on what is possible and desirable, has so far limited further action aimed at reducing risk and building resilience to volcanic hazards over the longer-term. 


\section{Discussion}

This paper describes the hazard context and the dilemmas this poses for risk-sensitive development on the island of SVG, which in many ways serves as an exemplar for all volcanic SIDS. The authors argue that the volcano and the secondary hazards associated with volcanic activity are critical factors shaping the development of SVG, constraining options for physical development on the island of St Vincent and, by extension, economic growth and sustainability, because of the very limited land-use options available. The volcano itself and its steep landslide-prone slopes, combined with limited coastal plains, much of which is at risk from storm surge and flooding, severely restrict locations suitable for "safe" or low-risk development. Nonetheless, those populations most exposed to volcanic hazards have benefited from improved services and substantial investments in infrastructure in recent years, supported by government efforts to decentralise growth away from the crowded capital and to reverse years of stagnation of the rural economy in the north. Without these improvements, these marginal high-risk areas would continue to decline-and therein lies the dilemma in pursuing the desirable policy goal of risk-sensitive development.

Reducing the risk from volcanic hazards is not a priority in planning decisions in SVG, nor is avoiding risk accumulation in hazard-prone areas. There is no plan to resettle populations living close to the volcano, although this could change in the short term if levels of volcanic activity increase. Recent investments in the Georgetown area have been undertaken largely in the absence of disaster risk assessments. The Draft Physical Development Plan-the instrument guiding long-term development in SVG-pays little attention to issues of hazard exposure, focusing instead on the critical and more visible issues of reducing over-population and pressure on services in the south and generating economic growth and prosperity in the north. Yet, as one planner admits, "The challenge of coming up with a long-term plan for a volcano ( . . ) is mentally daunting but something we would have to face" (17 June 2014). Discussions with government officials overall suggest an increasing awareness of volcanic risk and a desire to understand better the risks to their sectors. Options for protecting infrastructure from ash, for example, are seen as worthy of consideration by some government officials, who are also keen to have the tools to support detailed risk assessments.

Measures to protect infrastructure from multiple hazards should be sought in all volcanic SIDS, enhancing co-benefits where possible. One example is making sure buildings and roofs are ash- as well as hurricane-proof. Discouraging housing development in topographic lows or on unstable hill slopes would also reduce the impacts of eruptions on housing. In designing new drains, assessments of heavy sediment flows as well as water can be incorporated. Check dams on hillsides could be built for lahars, not just soil from erosion. In summary, there are clear benefits to developing household, community and government plans that have mutual or cumulative benefits for risk reduction across different hazard scenarios.

Government-led actions should consider both the short- and longer-term risks associated with volcanic and related hazards. In the short term, if there is elevated volcanic activity, governments are likely to increase monitoring, awareness-raising and capacity-building for emergency response. How communities respond to heighted activity and alerts will, however, depend on preparedness planning that has taken place in advance. Government plans should include options for evacuating livestock and other assets to enhance recovery and adaptation. Households should have their own preparedness plans for a range of hazards, updated on the basis of regular simulation exercises.

Strengthening resilience over the longer term to ensure communities can recover and to limit impacts from renewed activity is more challenging. It is recognised that a full eruption would occasion evacuation and potentially relocation of the affected population. Options for increasing resilience to these kinds of major upheavals could include low-cost insurance for families living in high-risk areas. This would help them cope with disaster, recover livelihoods and even support relocations. Risk-pooling arrangements exist (for example the Caribbean Catastrophic Risk Insurance Fund), but these need to be extended to include a wider range of countries (not just neighbouring countries where risk and growth rates may be highly correlated). Identifying potential alternative farming 
land for displaced farmers would also assist in recovery. All these actions need to be considered and included in the National Disaster Management Plan. Volcanic and other risks should also be considered in longer-term development planning, with recent hazard maps used to inform decisions.

Despite the huge challenges facing volcanic islands like SVG, there are options for risk-sensitive development and economic growth. By understanding the range of risks and seeking measures that limit damage from multiple hazards, it is possible to partly overcome the particular problem of low awareness and attention paid to volcanic risk. In addition, by planning for recovery and supporting adaptation over the longer term, governments can help build the resilience of those living closest to volcanoes and limit the social and economic impact of an eruption.

The findings from this research have been deliberated with those responsible for DRM and physical planning in SVG and are now being used to highlight areas of policy and planning where knowledge of volcanic hazards could be better integrated.

Acknowledgments: The authors would like to thank Catherine Simonet, Grace Whitby, Meisha Forrest, Allanson Cruickshank, Ore Kolade and Patrick Ward for their help with data collection and analysis as well as the production of graphics for this paper. Research was conducted under the STREVA project (NE/J020052/1), funded by the NERC/ESRC Increasing Resilience to Natural Hazards in Earthquake-Prone \& Volcanic Regions programme.

Author Contributions: Emily Wilkinson and Barbara Carby conceived and designed the research questions and interview protocols; Barbara Carby, Emily Wilkinson and Emma Lovell conducted the interviews and attended the workshops; Emma Lovell, Emily Wilkinson, Barbara Carby Jenni Barclay and Richie Robertson compiled and analysed the data; all authors contributed to the writing of the paper.

Conflicts of Interest: The authors declare no conflict of interest.

\section{References}

1. Global Facility for Disaster Risk Reduction (GFDRR). St. Vincent and the Grenadines. Disaster Risk Management in Latin America and the Caribbean Region; GFDRR Country Note; World Bank: Washington, DC, USA, 2010.

2. DIPECHO LAC. 8.0 Strategic Direction for Disaster Risk Reduction in SVG. 2014. Available online: http:/ / dipecholac.net/docs/files/789-cd-svg.pdf (accessed on 14 September 2015).

3. UN Office for Disaster Risk Reduction (UNISDR). Global Assessment Report on Disaster Risk Reduction; UN Office for Disaster Risk Reduction (UNISDR): Geneva, Switzerland, 2009.

4. UN Office for Disaster Risk Reduction (UNISDR). Global Assessment Report on Disaster Risk Reduction; UN Office for Disaster Risk Reduction (UNISDR): Geneva, Switzerland, 2015.

5. Robertson, R.E.A. An assessment of the risk from future eruptions of the Soufriere Volcano of St. Vincent, West Indies. Nat. Hazards 1995, 11, 163-191. [CrossRef]

6. Robertson, R.E.A. St. Vincent. In Volcanic Hazard Atlas of the Lesser Antilles; Lindsay, J.M., Robertson, R.E.A., Shepherd, J.B., Ali, S., Eds.; Seismic Research Unit, University of the West Indies: St Augustine, Trinidad and Tobago, 2005; pp. 241-273.

7. St. Vincent and Grenadines (SVG). St Vincent and the Grenadines Draft National Physical Development Plan; Government of Saint Vincent and the Grenadines: Kingstown, St. Vincent and the Grenadines, 2001; Volume 1.

8. World Bank. Population. Total. World Bank Dataset for 2013. Available online: http://data.worldbank.org/ indicator/SP.POP.TOTL (accessed on 15 February 2016).

9. Faria, B.; Fonseca, J.F.B.D. Investigating volcanic hazard in Cape Verde Islands through geophysical monitoring: Network description and first results. Nat. Hazards Earth Syst. Sci. 2014, 14, 485-499. [CrossRef]

10. Morin, J.; Lavigne, F.; Bachelery, P.; Finizola, A.; Villeneuve, N. Institutional and social responses to hazards related to Karthala volcano, Comoros. Shima Int. J. Res. Isl. Cult. 2009, 3, 33-53.

11. Loughlin, S.; Sparks, S.; Brown, S.; Jenkins, S.; Vye-Brown, C. Global Volcanic Hazards and Risk; Cambridge University Press: Cambridge, UK, 2015.

12. Lindsay, J.M.; Robertson, R.E.A.; Shepherd, J.B.; Ali, S. (Eds.) Volcanic Hazard Atlas of the Lesser Antilles; Seismic Research Unit, University of the West Indies: St Augustine, Trinidad and Tobago, 2005.

13. Opadeyi, J.; Ali, S.; Chin, E. Status of Hazard Maps, Vulnerability Assessments and Digital Maps in the Caribbean; Final Report; Caribbean Disaster Emergency Response Agency (CDERA): Bridgetown, Barbados, 2003. 
14. Cronin, S.J.; Neall, V.E. Holocene volcanic geology, volcanic hazard, and risk on Taveuni, Fiji. N. Z. J. Geol. Geophys. 2001, 44s, 417-437. [CrossRef]

15. Hicks, A.; Few, R. Trajectories of social vulnerability during the Soufrière Hills volcanic crisis. J. Appl. Volcanol. 2015, 4. [CrossRef]

16. Woo, G. Probabilistic criteria for volcano evacuation decisions. Nat. Hazards 2008, 45, 87-97. [CrossRef]

17. Easterly, W.; Kraay, A. Small states, small problems? Income, growth and volatility in small states. World Dev. 2000, 28, 2012-2027. [CrossRef]

18. Ferdinand, I.; O’Brien, G.; O’Keefe, P.; Jayawickrama, J. The double bind of poverty and community disaster risk reduction: A case study from the Caribbean. Int. J. Disaster Risk Reduct. 2012, 2, 84-94. [CrossRef]

19. Kelman, I. No change from climate change: Vulnerability and small island developing states. Geogr. J. 2013, 180, 120-129. [CrossRef]

20. Pelling, M.; Uitto, J.I. Small island developing states: Natural disaster vulnerability and global change. Environ. Hazards 2001, 3, 49-62.

21. UN Conference on Trade and Development (UNCTAD). The Vulnerability of Small Island Developing States in the Context of Globalisation; UN Conference on Trade and Development (UNCTAD): Geneva, Switzerland, 2007.

22. Dibben, C.; Chester, D. Human vulnerability in volcanic environments: The case of Furnas, Sao Miguel, Azores. J. Volcanol. Geotherm. Res. 1999, 92, 133-150. [CrossRef]

23. Kelman, I. Disaster risk governance for Pacific island communities. Asia Pac. J. Jpn. Focus 2005, 13, 48.

24. Mercer, J.; Dominey-Howes, D.; Kelman, I.; Lloyd, K. The potential for combining indigenous and western knowledge in reducing vulnerability to environmental hazards in small island developing states. Environ. Hazards 2007, 7, 245-256. [CrossRef]

25. Briguglio, L. Small island developing states and their economic vulnerabilities. World Dev. 1995, 23, 1615-1632. [CrossRef]

26. Commonwealth Consultative Group. A Future for Small States: Overcoming Vulnerability; Commonwealth Secretariat: London, UK, 1997.

27. Connell, J. Sovereignty and Survival: Island Micro-States in the Third World; Monography No. 3; University of Sydney, Department of Geography: Sydney, Australia, 1997.

28. Boruff, B.J.; Cutter, S. The environmental vulnerability of Caribbean Island nations. Geogr. Rev. 2007, 97, 24-45. [CrossRef]

29. Méheux, K.; Dominey-Howes, D.; Lloyd, K. Natural hazard impacts in small island developing states: A review of current knowledge and future research needs. Nat. Hazards 2007, 40, 429-446. [CrossRef]

30. Kelman, I. Hearing local voices from small island developing states for climate change. Local Environ. 2010, 15, 605-619. [CrossRef]

31. Rampengan, M.M.F.; Boedhihartono, A.K.; Law, L.; Gaillard, J.C.; Sayer, J. Capacities in facing natural hazards: A small island perspective. Int. J. Disaster Risk Sci. 2014, 5, 247-264. [CrossRef]

32. Terry, J.P.; Goff, J.R. The special vulnerability of Asia-Pacific islands to natural hazards. In Natural Hazards in the Asia-Pacific Region: Recent Advances and Emerging Concepts; Terry, J.P., Goff, J.R., Eds.; The Geological Society: London, UK, 2012; pp. 3-6.

33. Wisner, B.; Blaikie, P.; Cannon, T.; Davis, I. At Risk: Natural Hazards, People's Vulnerability and Disasters, 2nd ed.; Psychology Press: London, UK; New York, NY, USA, 2004.

34. Ahmad, R. Risk Management, Vulnerability and Natural Disasters in the Caribbean; Report for the IFRC; Department of Geography and Geology, Unit for Disaster Studies, University of the West Indies: Kingston, Jamaica, 2007.

35. McGuire, W.J.; Solana, M.C.; Kilburn, C.R.J.; Sanderson, D. Improving communication during volcanic crises on small, vulnerable islands. J. Volcanol. Geotherm. Res. 2009, 183, 63-75. [CrossRef]

36. Siebert, L.; Simkin, Y.; Kimberly, P. Volcanoes of the World; University of California Press: Berkeley, CA, USA, 2010.

37. Wilkinson, E. Transforming Disaster Risk Management: A Political Economy Approach; ODI Background Note; Overseas Development Institute: London, UK, 2012.

38. Kelman, I.; Mather, T.A. Living with volcanoes: The sustainable livelihoods approach for volcano-related opportunities. J. Volcanol. Geotherm. Res. 2008, 172, 189-198. [CrossRef]

39. Wilkinson, E. Beyond the volcanic crisis: Co-governance of risk in Montserrat. J. Appl. Volcanol. $2015,4$. [CrossRef] 
40. Wilkinson, E.; Brenes, A. Risk-Informed Decision-Making: An Agenda for Improving Risk Assessments under HFA2; The Climate and Development Knowledge Network (CDKN): London, UK, 2014.

41. Carby, B. Beyond the community: Integrating local and scientific knowledge in the formal development approval process in Jamaica. Environ. Hazards 2015, 14, 252-269. [CrossRef]

42. Mercer, J.; Kelman, I.; Taranis, L.; Suchet-Pearson, S. Framework for integrating indigenous and scientific knowledge for disaster risk reduction. Disasters 2010, 34, 213-248. [CrossRef] [PubMed]

43. Bahadur, A.; Peters, K.; Wilkinson, E.; Pichon, F.; Gray, K.; Tanner, T. The 3As: Tracking Resilience Across BRACED; BRACED Working Paper; The Overseas Development Institute (ODI): London, UK, 2015.

44. Manyena, B.M. The concept of resilience revisited. Disasters 2006, 30, 433-450. [CrossRef] [PubMed]

45. Kenny, C. Why Do People Die in Earthquakes? The Costs, Benefits and Institutions of Disaster Risk Reduction in Developing Countries; Policy Research Working Paper 4823; World Bank: Washington, DC, USA, 2009.

46. Rampengan, M.M.F.; Boedhihartono, A.K.; Margules, C.; Sayer, J.; Law, L.; Gaillard, J.-C.; Ong, T.N.T.; Tran, T.M.L. Agroforestry on an active volcanic small island in Indonesia: Prosperity with adversity. Geogr. Res. 2015, 54, 19-34. [CrossRef]

47. Stone, J.; Barclay, J.; Simmons, P.; Cole, P.D.; Loughlin, S.C.; Ramon, P.; Mothes, P. Risk reduction through community-based monitoring: The vigías of Tungurahua, Ecuador. J. Appl. Volcanol. 2014, 3, 1-14. [CrossRef]

48. EMDAT. Available online: http://www.emdat.be (accessed on 17 February 2016).

49. Robertson, R.E.A.; Samuel, A.; Shepherd, J.; Lynch, L.; Latchman, J. Monitoring volcanic activity at the Soufrière Volcano-A model for volcano monitoring operations in small-island nations. In Proceedings of the Conference on Beyond Walls: Multi-Disciplinary Perspectives, Kingstown, St. Vincent and the Grenadines, 22-24 May 2003.

50. Van Westen, C.; Jetten, V.; Trigg, M.; Alkema, D. CHARIM-Caribbean Handbook on Risk Information Management Report on Methodologies for Hazard Mapping in the Caribbean. Suggested Methods for Analysis at Various Scales. The World Bank Group, ACP-EU Natural Disaster Risk Reduction Program, 2015, Version 3. Available online: http://www.charim.net/sites/default/files/handbook/otherpages/CHARIM\% 20Methodology\%20Report.pdf (accessed on 4 May 2016).

51. Caribbean Disaster Emergency Management Agency (CDEMA). Deadly Low-Level Trough System Impacts Dominica, Saint Lucia and Saint Vincent \& the Grenadines; Situation Report \#4. Available online: http:/ / reliefweb.int/report/saint-vincent-and-grenadines/situation-report-4-deadly-low-leveltrough-system-impacts (accessed on 15 February 2016).

52. Pyle, D.M.; Barclay, J. The 1902-3 eruptions of the Soufriere, St. Vincent: Impacts, relief and response. J. Hist. Geogr. Under review.

53. Flett, T.; Anderson, J.S. Report on the eruption of the Soufrière of St. Vincent in 1902 and on a visit to Montagne Pelèe in Martinique. Part I. R. Soc. Philos. Trans. Ser. 1903, A-200, 353-553.

54. UN Department for Social and Economic Affairs (NDESA). Saint Vincent and the Grenadines. Public Administration Country Profile; Division for Public Administration and Development Management (DPADM) UN Department for Social and Economic Affairs (UNDESA): New York, NY, USA, 2004.

55. Commonwealth Local Government Forum (CLGF). Commonwealth Local Government Handbook 2013/14; Commonwealth Local Government Forum (CLGF): London, UK, 2015.

56. Isaacs, P. Sustainable Land Management: St Vincent and Grenadines; SVG Land Policy Issues Paper: Kingstown, St. Vincent and the Grenadines, 2013.

57. St. Vincent and Grenadines (SVG). Saint Vincent and the Grenadines National Emergency and Disaster Management Act 2006. Government of Saint Vincent and the Grenadines: Kingstown, Jamaica, 2006. Available online: http:/ / faolex.fao.org/docs/pdf/stv137162.pdf (accessed on 14 September 2015).

58. National Emergency Management Organisation (NEMO). St Vincent and the Grenadines National Disaster Plan; National Emergency Management Organisation (NEMO): Kingstown, St. Vincent and Grenadines, 2005.

59. St Vincent and Grenadines (SVG). National Economic and Social Development Plan 2013-2025; Central Planning Division, Ministry of Finance and Economic Planning; St Vincent and Grenadines (SVG): Kingstown, Jamaica, 2013.

(C) 2016 by the authors; licensee MDPI, Basel, Switzerland. This article is an open access article distributed under the terms and conditions of the Creative Commons Attribution (CC-BY) license (http://creativecommons.org/licenses/by/4.0/). 